\title{
Sphaeridiotrema globulus (Rudolphi, 1814) (Digenea): evidence for two species known under a single name and a description of Sphaeridiotrema pseudoglobulus n.sp.
}

\author{
J. Daniel Mclaughlin \\ Department of Biology, Concordia University, 1455 de Maisonneuve Boulevard West, \\ Montréal, Qué., Canada H3G IM8 \\ MaRilyn E. SCOTT \\ Institute of Parasitology, McGill University, 21111 Lakeshore Road, Ste. Anne de Bellevue, Que., Canada H9X ICO \\ AND \\ JANE E. HUFFMAN \\ Department of Biological Sciences, East Stroudsburg University, East Stroudsburg, PA 18301, U.S.A.
}

Received June 11, 1992

Accepted October 19. 1992

\begin{abstract}
Mclaughlin, J. D., Scott, M. E., and Huffman, J. E. 1993. Sphaeridiotrema globulus (Rudolphi, 1814) (Digenea): evidence for two species known under a single name and a description of Sphaeridiotrema pseudoglobulus n.sp. Can. J. Zool. 71: $700-707$.

Experimental infection of domestic ducklings with metacercariae believed to be those of Sphaeridiotrema globulus from snails in Quebec, Canada. and New Jersey, U.S.A.. revealed that there are two species known under this name. Study of museum specimens has confirmed that the New Jersey specimens represent the original $S$. globulus: the specimens from Quebec represent a new species. The two species can be separated reliably on the basis of egg size: $S$. globulus (New Jersey) has smaller eggs (mean $97 \pm 4(\mathrm{SD}) \mu \mathrm{m}$; range $91-108 \mu \mathrm{m}$ ) than $S$. pseudoglobulus $\mathrm{n} . \mathrm{sp}$. from Quebec (mean $116 \pm 5 \mu \mathrm{m}$ : range $103-125 \mu \mathrm{m}$ ). The cirrus in $S$. pseudoglobulus has a basal bulb not found in that of $S$. globulus. There are fewer uterine coils anterior to the acetabulum in $S$. pseudoglobulus. Comparison of 6-day-old populations of each species revealed several statistically significant differences in the mean size of internal organs. The overall sizes of the body, ovary, and eggs and the width of the posterior testis were greater in $S$. pseudoglobulus; the pharynx, length of the posterior testis, and number of eggs in the uterus were greater in $S$. globulus. No differences were found in the size of the oral sucker, acetabulum. or anterior testis.
\end{abstract}

Mclaughtin, J. D., ScotT, M. E., et Huffman, J. E. 1993. Sphaeridiotrema globulus (Rudolphi, 1814) (Digenea): evidence for two species known under a single name and a description of Sphaeridiotrema pseudoglobulus n.sp. Can. J. Zool. $71: 700-707$.

Des expériences d’infection de canards domestiques avec des métacercaires de ce que nous croyions être Sphaeridiotrema globulus provenant d'escargots du Québec. Canada, et du New Jersey, États-Unis, ont montré qu’il y avait deux espèces associées sous ce nom. L'examen de matériel de musée a confirmé que les spécimens du New Jersey représentent l'espèce originale $S$. globulus et que les spécimens québécois appartiennent à une espèce inédite. Les deux espèces se distinguent de façon sûre d'après la taille des oeufs : S. globulus (New Jersey) a des oeufs plus petits (moyenne $97 \pm 4 \mu \mathrm{m}$ (écart type); étendue $91-108 \mu \mathrm{m}$ ) que ceux de $S$. pseudoglobulus n.sp. du Québec (moyenne $116 \pm 5 \mu \mathrm{m}$. étendue $103-125 \mu \mathrm{m}$ ). Seul le cirre de $S$. pseudoglobulosus possède un bulbe basal. Il y a aussi chez cette espèce moins de circonvolutions utérines antéiciures à l'acétabulum. Des comparaisons de populations des deux espèces à l'âge de 6 jours ont montré plusieurs différences significatives dans la taille moyenne des organes internes. En général, le corps. l'ovaire, les oeufs et la largeur du testicule postérieur étaient plus grands chez $S$. pseudoglobulosus, alors que le pharynx, la longueur du testicule postérieur et le nombre d’oeufs dans l'utérus étaient plus grands chez $S$. globulosus. Il n’y avait pas de différence de taille dans la ventouse orale, l'acétabulum et le testicule antérieur.

[Traduit par la rédaction]

\section{Introduction}

Sphaeridiotrema globulus (Rudolphi, 1814) is a cosmopolitan digenean that infects the digestive tract of waterfowl. It causes a severe enteritis that may be fatal to the host. Huffman and Roscoe (1989) and Mucha and Huffman (1991) have studied the pathogenic effects of this fluke in experimentally infected mute swans (Cygnus olor), Canada geese (Branta canadensis), and mallard ducks (Anas platyrhynchos) and have confirmed that this organism is the etiological agent responsible for the pathogenesis reported by earlier authors (e.g., Price 1934; Testi 1962; Francalanci and Manfredini 1969; Campbell and Jackson 1977; Roscoe and Huffman 1982, 1983).

Sphaeridiotrema globulus has recently been implicated in annual late-summer mortality of dabbling ducks (Anas spp.) in southwestern Quebec observed by Hoeve and Scott (1988). They reported heavy infections of $S$. globulus in dead ducks found in late summer and suggested that this parasite might be a factor in recurring annual mortality previously believed to be due to another digenean, Cyathocotyle bushiensis Khan, 1962, by Gibson et al. (1972). However, the typical enteritis reported by Huffman and Roscoe (1989) did not occur in ducklings experimentally infected with Sphaeridiotrema from southern Quebec (Gagnon 1990; C. Gagnon, unpublished data).

Given the apparent variability in pathogenesis, there is a practical need to distinguish between the different populations of this fluke. This study compares the morphology and morphometrics of adult Sphaeridiotrema grown experimentally in domestic ducklings from metacercariae obtained locally near Montréal, Quebec, and from New Jersey, U.S.A. We present data showing that the adults from the two localities can be differentiated on morphological and statistical grounds and that, in fact, two species are known as $S$. globulus. We pro- 
TABLE 1. Comparison of the morphometrics of 6-day-old Sphaeridiotrema from Quebec and New Jersey sources reared experimentally in domestic ducklings with those of $S$. globulus given by Price (1934)

\begin{tabular}{|c|c|c|c|c|c|c|c|c|}
\hline & \multicolumn{6}{|c|}{ Sphaeridiotrema } & \multirow[b]{3}{*}{$P$} & \multirow{3}{*}{$\begin{array}{l}\text { S. globulus } \\
\text { (Price 1934) }\end{array}$} \\
\hline & \multicolumn{3}{|c|}{ Quebec specimens } & \multicolumn{3}{|c|}{ New Jersey specimens } & & \\
\hline & Mean & SD & Range & Mean & $\mathrm{SD}$ & Range & & \\
\hline \multicolumn{9}{|l|}{ Body } \\
\hline Length (mm) & 1.1 & 0.1 & $0.9-1.38$ & 0.9 & 0.1 & $0.6-1.2$ & $* * *$ & $0.68-0.85$ \\
\hline Width $(\mathrm{mm})$ & 0.78 & 0.1 & $0.6-0.95$ & 0.7 & 0.9 & $0.5-1.02$ & $*$ & $0.56-0.79$ \\
\hline \multicolumn{9}{|l|}{ Oral sucker } \\
\hline Length & 138 & 16 & $120-182$ & 133 & 16 & $96-168$ & ns & \\
\hline Width & 173 & 22 & $125-216$ & 177 & 18 & $139-221$ & ns & $150-165^{a}$ \\
\hline \multicolumn{9}{|l|}{ Pharynx } \\
\hline Length & 96 & 12 & $72-120$ & 107 & 14 & $81-156$ & $* * *$ & 90 \\
\hline Width & 94 & 12 & $67-120$ & 106 & 18 & $72-156$ & $* * *$ & $60-75$ \\
\hline \multicolumn{9}{|l|}{ Acetabulum } \\
\hline Length & 347 & 54 & $240-480$ & 313 & 78 & $168-432$ & ns & $260-375$ \\
\hline Width & 419 & 34 & $336-475$ & 421 & 37 & $312-480$ & ns & $390-413$ \\
\hline \multicolumn{9}{|l|}{ Ovary } \\
\hline Length & 140 & 22 & $110-197$ & 113 & 14 & $86-144$ & $* * *$ & \\
\hline Width & 173 & 27 & $120-216$ & 136 & 17 & $96-182$ & $* * *$ & $135^{\prime}$ \\
\hline \multicolumn{9}{|l|}{ Anterior testis } \\
\hline Length & 218 & 42 & $120-288$ & 203 & 51 & $120-312$ & ns & $225-387^{b}$ \\
\hline Width & 279 & 47 & $168-360$ & 303 & 62 & $192-432$ & ns & $150-320^{\prime \prime}$ \\
\hline \multicolumn{9}{|l|}{ Posterior testis } \\
\hline Length & 160 & 41 & $96-288$ & 197 & 48 & $120-228$ & $* *$ & $225-387^{b}$ \\
\hline Width & 349 & 42 & $250-408$ & 297 & 49 & $206-408$ & $* * *$ & $150-320^{b}$ \\
\hline No. of eggs per fluke & 9 & 3 & $5-15$ & 23 & 10 & $6-50$ & $* * *$ & Up to 60 \\
\hline \multicolumn{9}{|l|}{ Eggs in utero } \\
\hline Length & 116 & 5 & $103-125$ & 97 & 4 & $91-108$ & $* * *$ & $90-105$ \\
\hline Width & 71 & 5 & $62-84$ & 63 & 4 & $53-72$ & $* * *$ & $60-67$ \\
\hline \multicolumn{9}{|l|}{ Egg in feces } \\
\hline Length & 126 & 5 & $120-136$ & 105 & 7 & $96-115$ & $* * *$ & \\
\hline Width & 82 & 2 & $76-89$ & 73 & 3 & $67-84$ & $* * *$ & \\
\hline
\end{tabular}

Note: Measurements are given in micrometres unless stated otherwise. Minimum $n=28$ for Quebec. 27 for New Jersey. One hundred fecal eggs were examined. Comparisons between experimental populations: ${ }^{*}, P<0.05$ : $^{* *}, P<0.01$ : ${ }^{* * *}, P<0.001$.

"Diameter.

${ }^{h}$ Anterior and posterior testes not reported separately.

pose that the specimens from Quebec are identical with those described as S. globulus by Szidat (1937) and represent a similar, but heretofore unrecognized, species.

\section{Materials and methods}

Metacercariae were obtained from Bithynia tentaculata collected from the Rivière du Sud, near Lacolle, Quebec, and from Goniobasis virginica collected from Lake Musconetong, New Jersey, referred to hereafter as the Quebec and New Jersey specimens, respectively. The snails from Quebec were crushed, then digested in acid pepsin at $40^{\circ} \mathrm{C}$ for $15 \mathrm{~min}$. The digest was passed through a $100 \mu \mathrm{m}$ mesh screen and the residue was searched microscopically for metacercariae. Metacercariae from New Jersey sources were removed from their snail hosts and shipped to Montréal in saline. The Quebec metacercariae were used fresh; those from New Jersey were 7-10 days old.

Domestic ducklings (Anas platyrhynchos) were obtained from Brome Lake Duck Farms, Knowlton, Quebec. They were maintained on a diet of unmedicated laying mash (Nutribec Ltd., Montréal) and were provided with food and water ad libitum.

Four 3-week-old ducklings were orally intubated with $80-100$ Quebec metacercariae. Four others received similar doses of New Jersey metacercariae. On day 5 postexposure, each duckling was isolated in a wire-bottomed cage for $2 \mathrm{~h}$. Eggs were collected by rinsing the feces through a series of screens $(100,70$, and $37 \mu \mathrm{m})$. Eggs trapped on the $37 \mu \mathrm{m}$ mesh screen were fixed in $5 \%$ formalin for later measurement. The ducklings were necropsied on day 6 postexposure Flukes were removed from the freshly opened intestine and rinsed in saline. and where necessary, pieces of tissue were removed from the acetabulum. Most flukes were flattened under cover-slip pressure. To ensure uniform flattening, a double strip of lens cleaning tissue (Kimwipes) was placed on either side of the specimen before the cover slip was applied. Specimens were fixed in 5\% formalin ( $24 \mathrm{~h})$, then stored in $70 \%$ ethanol. Specimens prepared as whole mounts were stained in acetocarmine. Some specimens were fixed without flattening. Most of these were sectioned at $10 \mu \mathrm{m}$ and stained in hematoxylin and eosin. The remaining specimens were critical-point dried, coated with gold, and examined on a Hitachi 520 scanning electron microscope to determine the presence of acetabular spines.

Specimens of comparable age from blue-winged teal (Anas discors) from another study (Gagnon 1990) were also used, as none of the Quebec specimens in this series had everted cirri. The teal had been exposed to metacercariae from the same locality as the ducklings in this experiment. Additional specimens of different ages from experimentally infected whistling swans and mallards (New Jersey) and blue-winged teal (Quebec) were also studied.

The following museum material was also examined: 10 specimens labelled as syntypes of $S$. globulus from the Berlin Museum (No. 1530); 20 specimens of $S$. globulus from lesser scaup (Aythya affinis) (USNM 75388, slide numbers M 1286-2 to -5); 2 specimens from a white-winged scoter (Melanitta fusca) (USNM 39557) identified by E. W. Price; a single specimen from a whistling (=tundra) swan, Cygnus columbianus (USNM 77455); and 10 paratype specimens of 
TABLE 2. Variation in body shape and in the arrangement of the ovary and testes in 6-day-old Sphaeridiotrema pseudoglobulus from Quebec and 6-day-old $S$. globulus from New Jersey sources reared experimentally in domestic ducklings, showing the percentage of the experimental population exhibiting each body shape or arrangement of ovary and testes

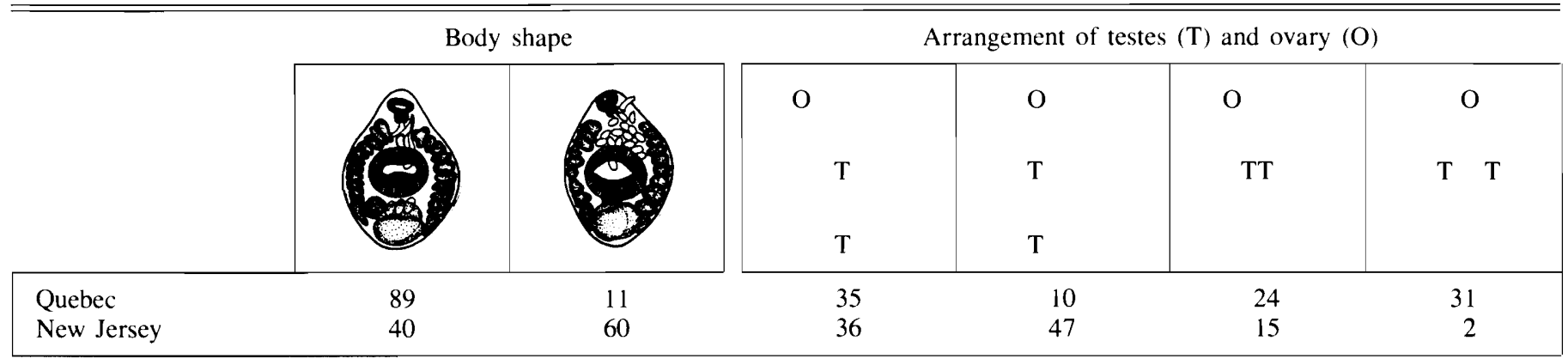

Sphaeridiotrema spinoacetabulum Burns, 1961 from domestic ducklings (USNM 38908) from the United States National Museum.

Measurements were made on a Wild M-20 microscope. Drawings were made with the aid of a Wild drawing tube.

Statistical analyses included $t$-tests, multiple regression, MANOVA, and discriminant analyses. Probabilities $<0.05$ were considered significant.

\section{Results}

Forty-four specimens from Quebec sources and 44 specimens from New Jersey sources were examined and measured. Complete sets of measurements (excluding those of the cirrus sac and cirrus) were obtained from 28 Quebec specimens and 27 New Jersey specimens.

Table 1 summarizes the measurements obtained from both experimental populations. Despite extensive overlap in the size ranges of most structures, significant differences occurred between the mean sizes of all structures but the oral sucker, acetabulum, and anterior testis. The mean lengths and widths of the body, ovary, uterine eggs, and free eggs and the width of the posterior testis were all significantly greater in the Quebec specimens. The mean dimensions of the pharynx, the length of the posterior testis, and the mean number of eggs in the uterus were significantly greater in the New Jersey specimens.

Representative specimens from the Quebec and New Jersey populations are shown in Figs. 1-5. Quebec specimens (Fig. 1) were mostly pyriform and had few uterine coils anterior to the acetabulum. The short cirrus was characterized by a conspicuous bulbous base (Fig. 2). Minute spine-like structures occurred on the acetabulum of several individuals (Figs. 9, 10).

The New Jersey specimens were more variable, ranging from pyriform to oval in shape (Figs. 3, 4). In most specimens, a number of uterine coils lay between the acetabulum and the genital pore. The cirrus of specimens in the experimental population (Fig. 5), although wider at the base than at the tip, lacked the basal bulb seen in the Quebec specimens. No acetabular spines were present on the eight specimens examined by scanning electron microscopy (SEM).

The body shape and positions of the ovary and testes varied extensively in the experimental populations. The percentage of individuals in each population exhibiting a particular shape or gonadal arrangement is given in Table 2 .

The cirrus sac and cirrus could only be measured in a few specimens and these measurements were not compared statistically. The measurements (given as the range followed by the mean \pm standard deviation in parentheses) of each are as fol- lows: Quebec specimens: cirrus sac $(n=10) 252-384 \mu \mathrm{m}$ $(307 \pm 43 \mu \mathrm{m})$ long $\times 48-84 \mu \mathrm{m}(69 \pm 11 \mu \mathrm{m})$ wide; cirrus $(n=7) 120-149 \mu \mathrm{m}(136 \pm 12 \mu \mathrm{m})$ long, basal bulb $48-$ $67 \mu \mathrm{m}(56 \pm 7 \mu \mathrm{m})$ wide, tip $17-27 \mu \mathrm{m}(22 \pm 4 \mu \mathrm{m})$, distance between bulb and tip $36-72 \mu \mathrm{m}(53 \pm 14 \mu \mathrm{m})$. New Jersey specimens: cirrus sac $(n=9) 225-336 \mu \mathrm{m}(283 \pm 33 \mu \mathrm{m})$ long $\times 38-67 \mu \mathrm{m}(49 \pm 10 \mu \mathrm{m})$ wide; cirrus $(n=5) 115-$ $168 \mu \mathrm{m}(145 \pm 22 \mu \mathrm{m})$ long, basal portion $44-48 \mu \mathrm{m}(46 \pm$ $2 \mu \mathrm{m})$ wide, tip $24-31 \mu \mathrm{m}(27 \pm 3 \mu \mathrm{m})$.

Specimens described by Price (1934) from lesser scaup from Maryland (Figs. 6-8) and those he identified from scoters from Ontario are similar to the New Jersey specimens. The only difference observed was the cirrus length. A cirrus observed in one of Price's specimens (USNM 75388, slide No. M 1286-5) was much longer (336 $\mu \mathrm{m}$ long $\times 72 \mu \mathrm{m}$ wide at the base and $34 \mu \mathrm{m}$ wide at the tip) (Fig. 8) than those observed in the experimental population. A specimen from a whistling swan in New Jersey (USNM 74455), identified by D. E. Roscoe, has a cirrus that is approximately $220 \mu \mathrm{m}$. These measurements indicate that the cirrus was not fully everted in the experimentally reared New Jersey specimens.

The type specimens of $S$. globulus were dry when received and had apparently been so for some time. Attempts to rehydrate them using trisodium phosphate (Pritchard and Kruse 1982) were unsuccessful. No internal details were visible in the 10 specimens examined. Some of the specimens collapsed under cover-slip pressure during mounting and several eggs were observed. These measured $80-96 \times 52-65 \mu$ m (mean $88 \times$ $57 \mu \mathrm{m})$. One specimen was prepared for SEM, but it was impossible to determine whether spines or spine-like structures were present.

Variables that differed significantly between the two groups (Table 1) were subjected to stepwise multiple regression. Two variables, egg number and the dimensions of the eggs collected from the feces, were not included. Six variables, body length, body width, pharynx width, and the lengths of the ovary, posterior testis, and the uterine eggs accounted for most of the variability $\left(R^{2}=0.94\right)$ and these were retained for further analysis. MANOVA performed on the reduced data set revealed that the mean vectors of the two groups were significantly different (Wilks' $\lambda=0.044, F_{|1.42|}=127.85, P<$ $0.0001)$, indicating that the two populations can be separated statistically using these variables. Subsequent discriminant function analysis revealed that egg length was the most important variable for separating the two groups. Egg length (Fig. 12) accounted for most of the variability between the samples (Wilks' $\lambda=0.1330$ ), and $96 \%$ of the specimens in the sample 

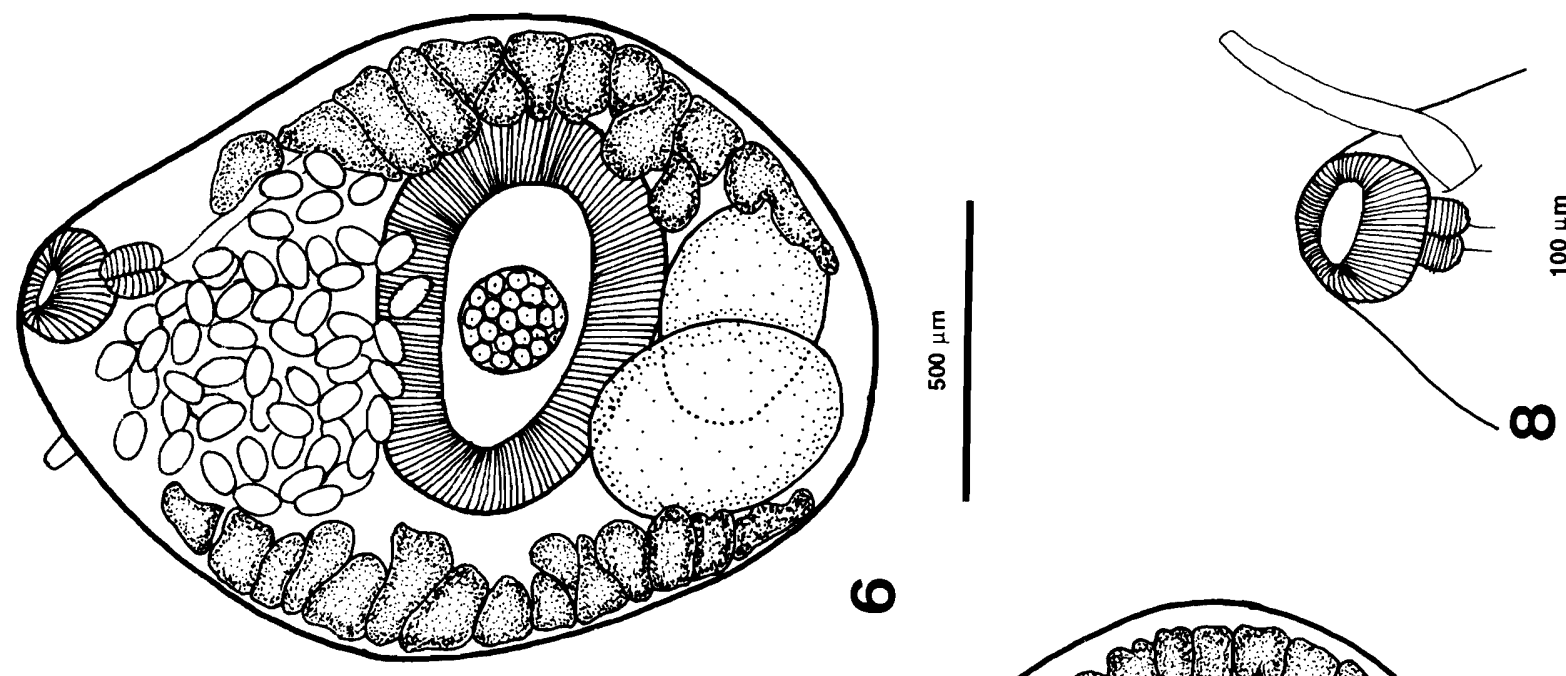

ن 家

舟总高它

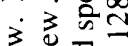

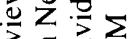

可苞完

5. 000

舟证

实 $\dot{\infty}$

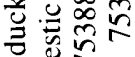

号芯致

记幻

월

马.

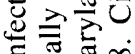

플

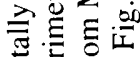
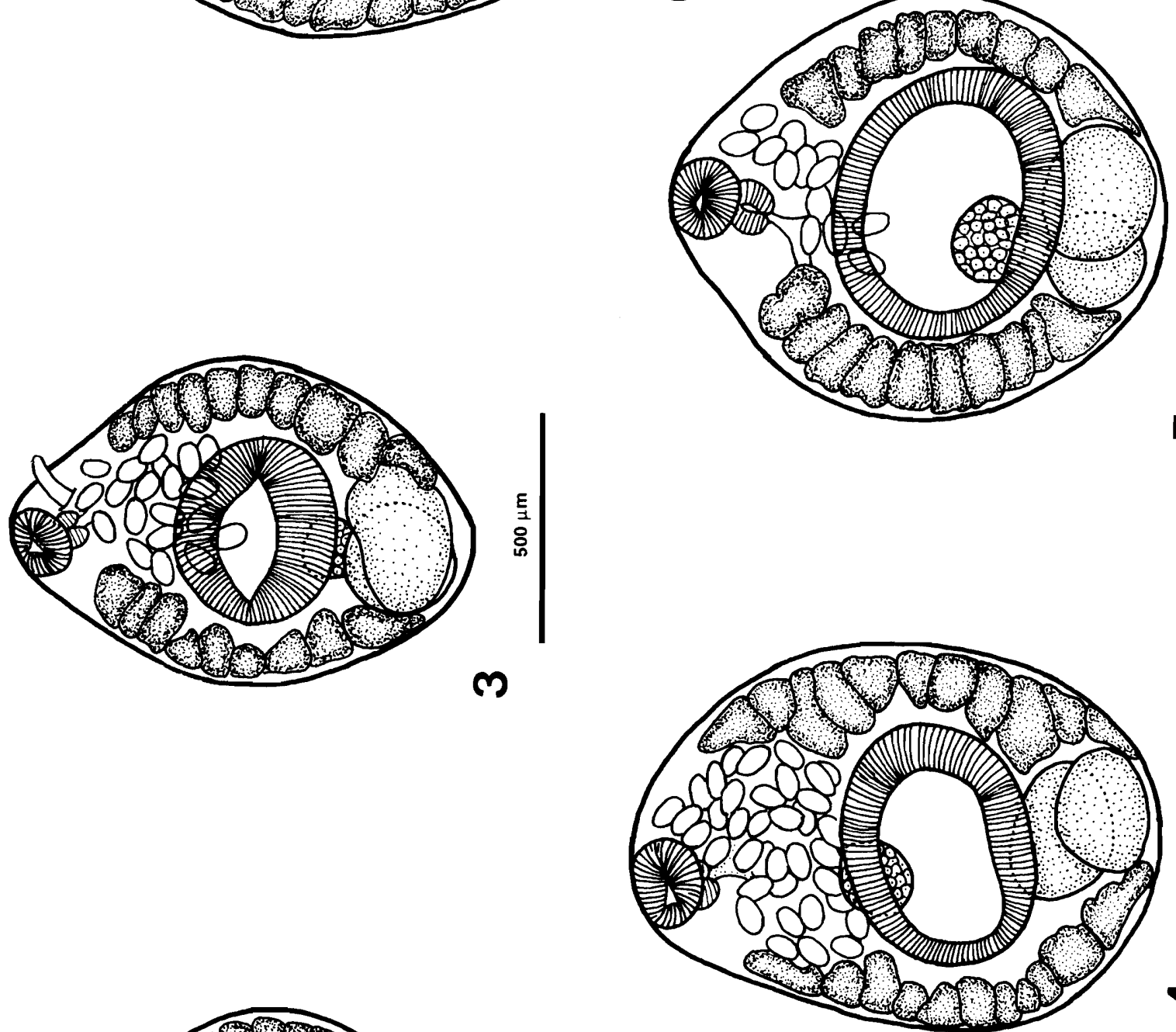

통

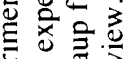

䠌

约

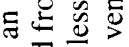

छ

혼

ปิ

寻志

के

궁ำ

ว

गิ

正密

艾密

产祌方

王的占

- m

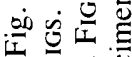

ن.

ष्ठ

跘的

ह

起江

的总完定

$=0$

芯芯离

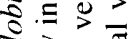

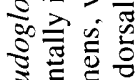
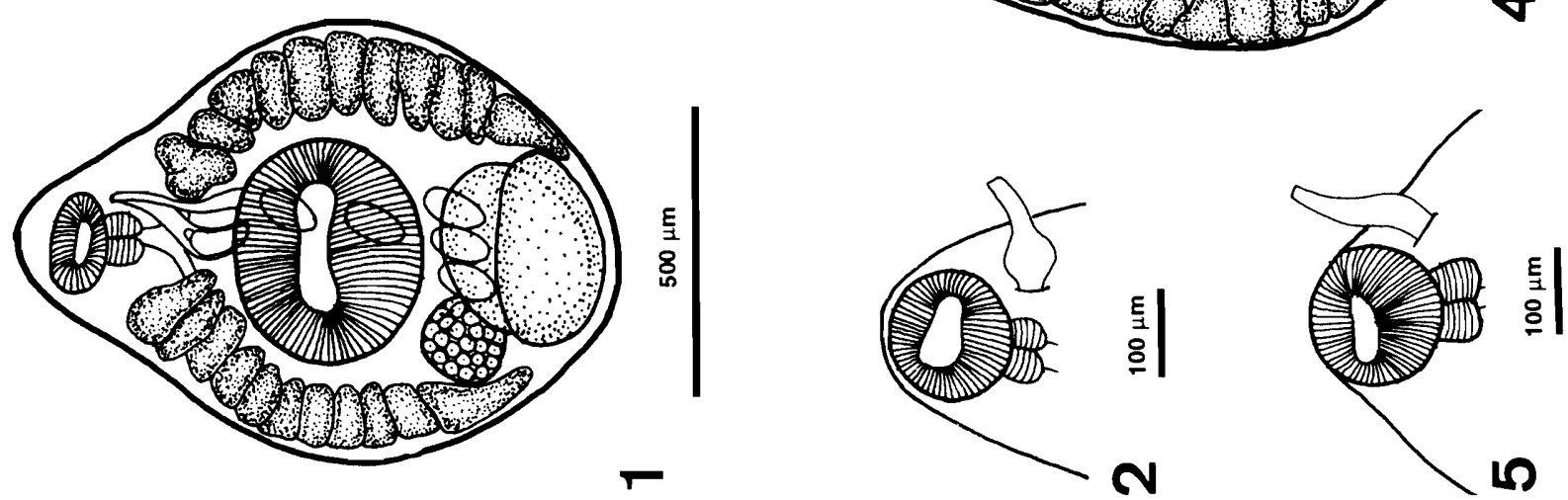

氖官

ฐ

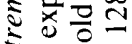

言范交

施

仓ㅇํㄹ

施皆

त. $\begin{aligned} & 2 \\ & \omega_{\infty}\end{aligned}$

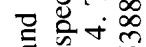

-

i $\mathrm{m} \sum$

至点密 


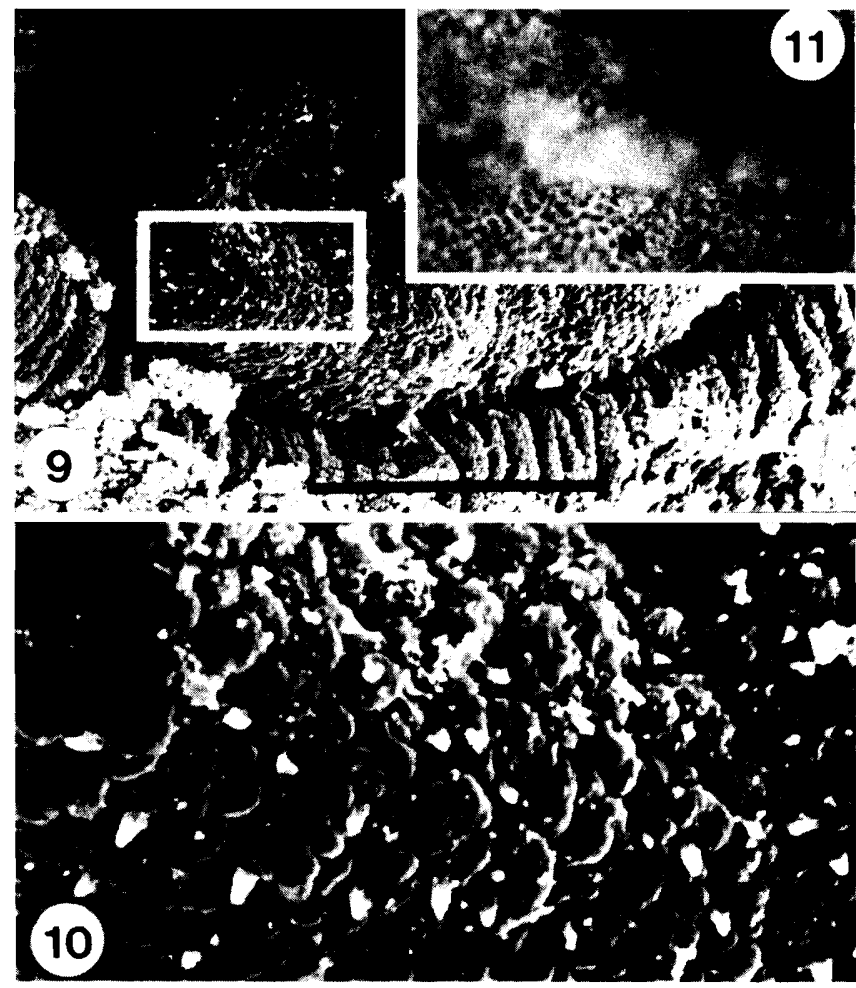

Figs. 9 and 10. Scanning electron micrographs of Sphaeridiotrema pseudoglobulus n.sp. Fig. 9. Paratype; acetabulum, showing minute spines. Scale bar $=50 \mu \mathrm{m}$. Fig. 10. Enlargement of portion of Fig. 9, showing spines. Scale bar $=250 \mu \mathrm{m}$. FiG. 11. Scanning electron micrograph of Sphaeridiotrema spinoacetabulum paratype (USNM 38908). Acetabulum, showing triangular spine-like structures around the edge. Scale bar $=10 \mu \mathrm{m}$.

could be correctly classified on this characteristic alone. Two specimens were misclassified among the 55 included in the original analysis. One Quebec specimen with eggs $103 \mu \mathrm{m}$ long and one New Jersey specimen with eggs $108 \mu \mathrm{m}$ long were classified incorrectly. When ovary length was included in the analysis, Wilks' $\lambda$ decreased to 0.0661 ; however, the percentage of correct classifications did not improve significantly (McNemar's test; $P>0.05$ ).

The analysis was repeated using an expanded data base that included egg measurements from those specimens from the original data set not included in the original discriminant function analysis, along with specimens of different ages and from different host species obtained in other experiments and from the museum specimens listed above. This increased the sample size to 217. An additional 10 cases were classified incorrectly. One Quebec specimen (eggs $101 \mu \mathrm{m}$ long) and nine New Jersey specimens (one each from an experimentally exposed wild-stock mallard, a domestic duck, and a scoter (USNM 39557) and six specimens from scaup (USNM 75388)) were classified incorrectly. All but one $(113 \mu \mathrm{m})$ had a maximum egg length of $108 \mu \mathrm{m}$ and all but two specimens resembled those shown in Figs. 6 and 7. Those that differed (108 and $113 \mu \mathrm{m})$ each had one egg in the uterus. The eggs from the type specimens were classified in the same group as those from the New Jersey specimens.

\section{Discussion}

Host species, parasite age, and fixation techniques are known to affect the morphology and morphometrics of flukes. Despite controlling for these factors, consistent morphometric and

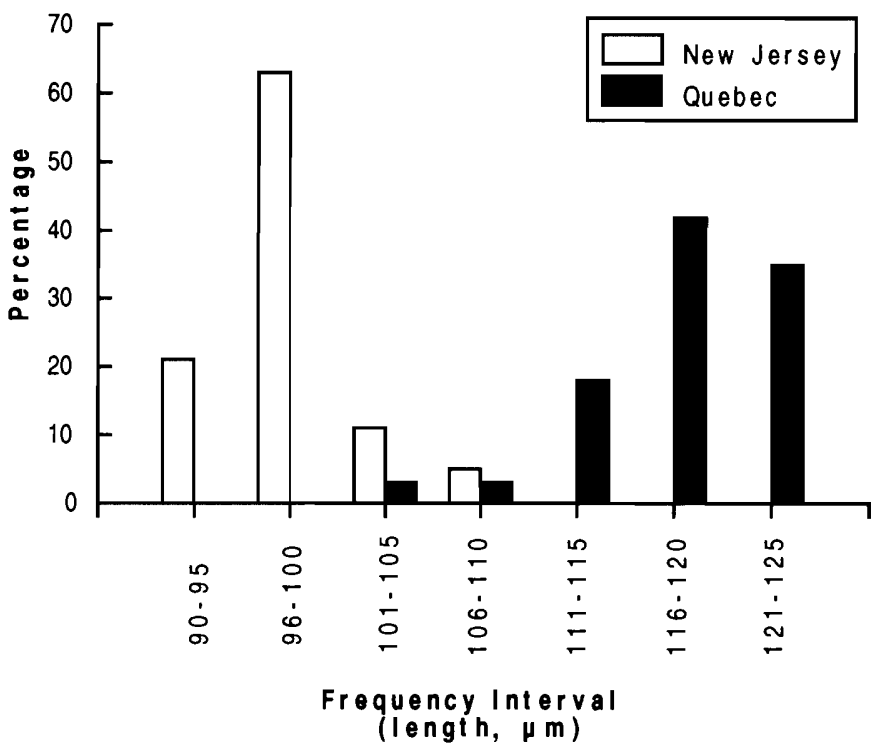

FiG. 12. Lengths of uterine eggs from 6-day-old specimens of Sphaeridiotrema pseudoglobulus n.sp. from Quebec compared with lengths of those from $S$. globulus from New Jersey reared experimentally in domestic ducklings.

morphological differences were observed between populations of Sphaeridiotrema reared from the Quebec and New Jersey sources. Specimens from the two sources can be distinguished most readily on the basis of egg length. Where the egg lengths overlap $(100-110 \mu \mathrm{m})$, uterine and cirrus characteristics reliably separate most specimens. As egg dimensions are neither subject to host-induced variation (Watertor 1967; Kinsella 1971; Blankespoor 1974) nor influenced by fluke age (Thomas 1965; Blankespoor 1974; Kinsella 1971), they provide a reliable and easily obtained means for rapid identification in this instance.

As observed by Price (1934) and Burns (1961), the early descriptions of $S$. globulus are incomplete and are insufficient for specific diagnosis. The earliest measurements available for S. globulus are in the brief descriptions by Braun (1902) and Odhner (1913). Price (1934) provided an extensive set of measurements but no illustrations; Szidat (1937) provided a detailed illustration but few measurements. Parenthetically, it is a copy of Szidat's specimen that is shown in Yamaguti (1971; Fig. 1248), not one from Odhner (1913) as stated.

Comparison of the measurements from each experimental population with those given by Price (1934) (Table 1) reveals that either could be identified with his material if egg size is disregarded. It is unfortunate that Price (1934) did not provide an illustration of his material because reexamination of his specimens has revealed that they differ morphologically from those described by Szidat (1937). As presently conceived, S. globulus is a composite species based partly on the descriptions in Price (1934) and Szidat (1937). Information from both sources has been used for identification purposes (e.g., Hoeve and Scott 1988) and by authors defining new species of Sphaeridiotrema (Burns 1961; Diaz 1980). The New Jersey specimens are identical with those described by Price (1934); the Quebec specimens are identical with those described by Szidat (1937). The question thus becomes which species, if either, is $S$. globulus and what is the identity of the other?

Braun (1902) provided a brief description of $S$. globulus based, in part, on the type specimens. Braun (1902) reported that the eggs were $104 \mu \mathrm{m}$ long. The egg lengths recorded 
from the syntypes examined in this study approximate the length reported by Braun (1902) and, if shrinkage due to drying is taken into account, lie well within the range reported by Price (1934) and established for the New Jersey specimens. Braun (1902) also provided drawings of the cirrus. The cirrus is wider at the base than at the tip but lacks a conspicuous bulbous base. It thus resembles the cirrus seen in the New Jersey material and in Price's specimens. The similarity in egg size and cirrus structure strongly suggests that the specimens described by Price (1934) and the New Jersey specimens represent the original $S$. globulus.

Price (1934) was the first to implicate $S$. globulus as a pathogen of waterfowl. This was confirmed experimentally (Huffman and Roscoe 1989), and other reports of pathogenesis due to intestinal infections with $S$. globulus seem to involve this species. Where egg measurements of specimens associated with intestinal enteritis were reported (Testi 1962; Francalanci and Manfredini 1969; Campbell and Jackson 1977), all fell within the range characteristic of this species.

Although Szidat (1937) was aware of the pathogenesis reported by Price (1934), he did not observe enteritis in ducklings he infected. Gagnon (1990) found lesions consisting of small denuded patches surrounded by enlarged microvilli, and vascular leakage, at sites where flukes were attached, but no evidence of hemorrhage or severe tissue damage in either domestic ducklings or blue-winged teal infected with metacercariae from Quebec sources. Sphaeridiotrema infections of the magnitude used by Gagnon (1990) (1-29 worms in domestic ducks; 47-89 worms in blue-winged teal) appear insufficient to cause serious pathogenesis in these hosts. The intensity of Sphaeridiotrema infections in ducks found dead (Hoeve and Scott 1988) is two orders of magnitude higher than that used by Gagnon (1990). This suggests that heavy infections of the Quebec form may indeed be fatal; however, the actual cause of the mortality is unknown. Hemorrhage and enteritis did occur in five domestic ducklings infected with 18-46 Sphaeridiotrema from New Jersey sources (unpublished data). The fact that there are two species known as $S$. globulus could account for the apparent discrepancies in the pathogenesis associated with this helminth.

The Quebec specimens (= Sphaeridiotrema globulus sensu Szidat 1937) do not resemble any of the species currently recognized in Sphaeridiotrema, and represent an undescribed species. A formal description is provided below.

\section{Sphaeridiotrema pseudoglobulus $\mathrm{n} . \mathrm{sp}$.}

Figs. 1, 2, 9, and 10 and Table 1 (under "Quebec specimens")

Synonym: Sphaeridiotrema globulus of Szidat, 1937 nec Rudolphi, 1814

\section{Diagnosis}

Psilostomidae Looss, 1900; Sphaeridiotrematinae Yamaguti, 1958. Description based on 44 whole mounts, 10 serially sectioned specimens, and 18 specimens prepared for SEM from experimentally infected domestic ducklings, and 7 specimens from experimentally infected blue-winged teal (cirri). All measurements are in micrometres $(\mu \mathrm{m})$ unless specified otherwise. Measurements presented are the range, with the mean in parentheses. Standard deviations are provided in Table 1.

Body (Fig. 1) pyriform to oval, 0.9-1.38 (1.1) mm long $\times$ $0.6-0.95(0.78) \mathrm{mm}$ wide; thick, globular in unflattened state. Body spines not observed. Oral sucker subterminal, oval, $120-182(138) \times 125-216(173)$. Acetabulum 240$480(347) \times 366-475(419)$, transversely oval, equatorial, twice as large as the oral sucker and with minute spine-like structures present on rim (Figs. 9, 10). Spines usually unobservable by light microscopy but readily observed using SEM. Prepharynx present but generally only visible in sagittal sections. Pharynx muscular, 72-120 (96) long $\times 67-120(94)$ wide. Esophagus short. Ceca extending to posterior limits of vitellaria. Genital pore ventral, sinistral, pre-bifurcal, situated at level of pharynx near posterior margin of oral sucker. Cirrus (Fig. 2) aspinous, 120-149 (136) long, with bulbous base $48-67$ (56) wide and narrower tubular portion $(36-72$ (53) long $\times 17-27$ (22) wide. Cirrus sac club-shaped, $252-$ $384(307) \times 45-84(69)$, may extend posteriorly as far as the anterior margin of the acetabulum or slightly beyond. Seminal vesicle present. Testes spherical to oval, subequal, situated posterior to acetabulum. Testes median, overlapping anterior to posterior in half of the specimens and laterally in the rest. Anterior testis $120-288(218) \times 168-360(279)$, dorsal, oval to suboval; posterior testis 96-288 (160) $\times 250-408$ (349), usually much wider than long. Ovary $110-197(140) \times$ $120-216$ (173), spherical to oval, dorsal, median in $41 \%$ of the specimens, submedian in the rest, usually overlapping anterior testis. Mehlis' gland present. Laurer's canal not observed. Seminal receptacle not observed. Vitelline follicles large, extending in lateral bands from level of pharynx to, but not beyond, posterior testis. Vitellaria enclose ceca along most of their length. Uterus with few coils posteriorly, generally straight from level of acetabulum to genital pore. Distal portion of uterus modified as a metraterm. Eggs few, 5-15 (9), $103-125(116) \times 62-84(71)$.

\section{Taxonomic summary}

TYPE HOST: Anas platyrhynchos, domestic form.

SITE: Intestine.

TYPE LOCAlity: Rivière du Sud, Quebec, Canada.

OTHER HOSTS: Natural infections (reported as $S$. globulus) in Aix sponsa, Aythya collaris, and several Anas species in southwestern Quebec (Hoeve and Scott 1988). Gagnon (1990) infected Anas discors experimentally with metacercariae from Bithynia tentaculata.

OTHER LOCALITIES: Local marshes near Montréal and Lac Saint-Pierre, Quebec, Canada; Kurischer Haff, Germany (Szidat 1937).

SPECIMENS: Sphaeridiotrema pseudoglobulus. National Parasite Collection, Canadian Museum of Nature (CMNP), Ottawa, Ontario, Canada KIV 7P1. Holotype: CMNP1992-0030; 6-day-old specimen from experimentally infected $A$. platyrhynchos. Paratypes: $n=10$, CMNP1992-0031 and the Helminthological Collection, United States National Museum, U.S. Department of Agriculture, Beltsville, Maryland (USNM), $n=5$, USNM 82575. Additional specimens from experimentally infected Anas discors showing cirrus $(n=2)$, CMNP1992-0032, 0033. Sphaeridiotrema globulus. Voucher specimens ( 6 days old, from experimentally infected $A$. platyrhynchos), $n=6$, CMNP1992-0034; $n=6$, USNM 82576. The type specimens of $S$. globulus (dry specimens, 7 slides and 1 SEM stub) were returned to Berlin.

\section{Remarks}

Four species, Sphaeridiotrema spinoacetabulum Burns, 1961, Sphaeridiotrema macrocotyla (Macy and Bell, 1968), Sphaeridiotrema newmillerdamensis Diaz, 1980, and Sphaeridiotrema monorchis Lin and Chen, 1983 are currently known from birds.

Sphaeridiotrema spinoacetabulum, described from experimentally infected domestic ducks, is a pathogenic species that 
infects the ceca rather than the intestine. Burns (1961) separated $S$. spinoacetabulum from $S$. globulus on the basis of adult morphology (as described by Price 1934) and the morphology of the cercariae (as described by Szidat 1937). There is extensive overlap between the measurements reported for $S$. spinoacetabulum and for $S$. pseudoglobulus. However, despite the fact that the specimens were also from domestic ducklings and were slightly older, the maximum dimensions of most structures in $S$. spinoacetabulum either approximated or were less than the mean size found in the new species. Minute spine-like structures occurred on the acetabulum of $S$. pseudoglobulus (Figs. 9, 10); however, these are not comparable to the triangular plate-like spines on S. spinoacetabulum (Fig. 11). The differences in the acetabular spines, the generally smaller organ sizes, and the differences in location and pathogenesis of flukes in domestic ducklings, along with the differences reported in the life cycle stages (Burns 1961), are sufficient to separate the two species.

Sphaeridiotrema newmillerdamensis was described from experimentally infected ducks and canaries (Diaz 1980). The oral sucker and acetabulum are approximately the same size and both the anterior part of the body and the margins of the acetabulum are densely spinous. Neither condition occurs in $S$. pseudoglobulus. The maximum dimensions of the acetabulum, ovary, cirrus sac, and testes in $S$. newmillerdamensis do not exceed $100 \mu \mathrm{m}$ and are much smaller than those in $S$. pseudoglobulus. Normally, only a single egg is present in the uterus of $S$. newmillerdamensis and the eggs $(79-83 \times$ 57-60) are much smaller than those of $S$. pseudoglobulus. Kanev and Vassilev (1984) included S. newmillerdamensis as a synonym of $S$. globulus. In view of the small size of the reproductive organs and the differences observed in body spination compared with that of the specimens of $S$. globulus described here, it is apparent that this synonymy should be rejected.

Macy and Bell (1968) erected the genus Astacatremulata for the species macrocotyla, separating it from Sphaeridiotrema by the presence of a larger, sac-like acetabulum, a genital pore located posterior to the intestinal bifurcation, a bipartite cirrus sac, testes arranged obliquely rather than tandemly, and a median ovary located laterally to the anterior testis. In addition, the metacercariae encyst on substrates external to the snail host and are not infective to ducklings (Macy and Bell 1968). The differences in the life cycle alone are sufficient to distinguish $S$. macrocotyla from the other species of the genus, and the validity of its inclusion in Sphaeridiotrema by Yamaguti (1971) is questionable.

Sphaeridiotrema monorchis has a single testis, according to Lin and Chen (1983), and is readily distinguishable from $S$. pseudoglobulus on this basis.

\section{Acknowledgements}

We thank Dr. Manfred Rau, Institute of Parasitology, McGill University, and Ms. Irene Mennagia for their generous help in translating the German, Ukrainian, and Russian papers. Dr. N. Kapoor, Concordia University, performed the scanning electron microscopy and assisted with the photography. Christine Gagnon, Institute of Parasitology, McGill University, provided additional specimens. Chris McKindsey, Concordia University, collected the snails at Rivière du Sud and helped infect and care for the ducks used in the study. We thank Dr. J. R. Lichtenfels, U.S. National Helminth Collec- tion, USDA, Beltsville, and Dr. G. Hartwich, Museum für Naturkunde der Humbolt-Universität, Berlin, for the loan of specimens in their respective institutions. This study was supported by a Concordia University Faculty Development Research Grant to J. D. McLaughlin, by the Fonds pour la formation de chercheurs et l'aide à la recherche (FCAR) pour l'aide et le soutien à la recherche (M. E. Scott and J. D. McLaughlin), and an East Stroudsburg Faculty Development Grant to J. E. Huffman. Research at the Institute of Parasitology is supported by the Natural Sciences and Engineering Research Council of Canada and by FCAR.

Blankespoor, H. 1974. Host-induced variation in Plagiorchis noblei Park, 1936 (Plagiorchiidae: Trematoda). Am. Midl. Nat. 92 415-433.

Braun, M. 1902. Fascioloiden der Vögel. Zool. Jahrb. 16

Burns, W. C. 1961. The life history of Sphaeridiotrema spinoacetabulum sp.n. (Trematoda: Psilostomidae) from the caeca of ducks. J. Parasitol. 47: 933-938.

Campbell, N. J., and Jackson, C. A. W. 1977. The occurrence of the intestinal fluke Sphaeridiotrema globulus in domestic ducks in New South Wales. Aust. Vet. J. 53: 29-31.

Diaz, M. T. 1980. Ciclo vital de Sphaeridiotrema newmillerdamensis n.sp. (Platyhelminthes, Trematoda). Acta Biol. Venez. 10: $497-$ 521 .

Francalanci, G., and Manfredini, L. 1969. La distoma intestinale dei volatili domestici da Sphaeridiotrema globulus (Rudolphi, 1814). Clin. Vet. (Milano), 92: 308-314.

Gagnon, C. 1990. Pathological consequences of infections by Cyathocotyle bushiensis Khan, 1962 and Sphaeridiotrema globulus (Rud., 1814) in two species of dabbling ducks. M.Sc. thesis, McGill University, Montréal, Quebec.

Gibson, G. G., Broughton, E., and Choquette, L. P. E. 1972. Waterfowl mortality caused by Cyathocotyle bushiensis Khan, 1962 (Trematoda: Cyathocotylidae), St. Lawrence River, Quebec. Can. J. Zool. 50: $1351-1356$.

Hoeve, J., and Scott, M. E. 1988. Ecological studies on Cyathocotyle bushiensis (Digenea) and Sphaeridiotrema globulus (Digenea), possible pathogens of dabbling ducks in southern Québec. J. Wildl. Dis. 24: $407-421$.

Huffman, J. E., and Roscoe, D. E. 1989. Experimental infections of waterfowl with Sphaeridiotrema globulus. J. Wildl. Dis. 25: $143-146$.

Kanev, I., and Vassilev, I. 1984. Morphology, biology and taxonomy of Sphaeridiotrema globulus (Rudolphi, 1819) Odhner, 1913. In Fauna, taksonmiya i ekologiya na khelminti po ptitsi. Edited by K. I. Vassilev. Bulgarian Academy of Science, Sofia. pp. $135^{-}$ 148 .

Kinsella, J. M. 1971. Growth, development, and intraspecific variation of Quinqueserialis quinqueserialis (Trematoda: Notocotylidae) in rodents. J. Parasitol. 7: 62-70.

Lin, X., and Chen, Q. 1983. Life-cycle studies of Sphaeridiotrema monorchis sp.nov. (Psilostomatidae). Acta Zool. Sin. 29: 333-339.

Macy, R. W., and Bell, W. D. 1968. The life cycle of Astacatremulata macrocotyla gen. et sp.n. (Trematoda; Psilostomidae) from Oregon. J. Parasitol. 54: 319-323.

Mucha, K. H., and Huffman, J. E. 1991. Inflammatory cell stimulation and wound healing in Sphaeridiotrema globulus experimentally infected mallard ducks (Anas platyrhynchos). J. Wildl Dis. 27: $428-434$.

Odhner, T. 1913. Zum natürlichen System der digenen Trematoden. VI. Zool. Anz. 42: 289-318.

Price, E. W. 1934. Losses among wild ducks due to infestation with Sphaeridiotrema globulus (Rudolphi) (Trematoda: Psilostomatidae). Proc. Helminthol. Soc. Wash. 1: $31-34$.

Pritchard, M. H., and Kruse, G. O. W. 1982. Collection and preservation of animal parasites. Tech. Bull. No. 1, The Harold W. 
Manter Laboratory, University of Nebraska Press, Lincoln and London.

Roscoe, D. E., and Huffman, J. E. 1982. Trematode (Sphaeridiotrema globulus)-induced ulcerative hemorrhagic enteritis in wild mute swans (Cygnus olor). Avian Dis. 26: 214-224.

Roscoe, D. E., and Huffman, J. E. 1983. A lethal Sphaeridiotrema globulus infection of a whistling swan. J. Wildl. Dis. 19: $370-$ 371.

Szidat. L. 1937. Über die Entwicklungsgeschichte von Sphaeridiotrema globulus Rud. 1814 und die Stellung der Psilostomidae Odhner im natürlichen System. I. Z. Parasitenkd. 9: 528-543.
Testi, F. 1962. Sphaeridiotrema globulus (Rudolphi, 1814) Odhner, 1913 in anitra domestica. Nuova Vet. 38: $150-153$.

Thomas, J. D. 1965. The anatomy, life history and size allometry of Mesocoelium monodi Dollfus, 1929. J. Zool. (1965-1984), 146: 413-446.

Watertor, J. L. 1967. Intraspecific variation of adult Telorchis bonnerensis (Trematoda: Telorchiidae) in amphibian and reptilian hosts. J. Parasitol. 53: $962-968$.

Yamaguti, S. 1971. Synopsis of digenetic trematodes of vertebrates. Vols. 1 and 2. Keigaku Publishing Co., Tokyo. 